\title{
Oxidative Stress Induces Expression of the Toll-Like Receptors (TLRs) 2 and 4 in the Human Peripheral Blood Mononuclear Cells: Implications for Metabolic Inflammation
}

\author{
Nadeem Akhter ${ }^{\mathrm{a}} \quad$ Ashraf Madhoun $^{\mathrm{b}} \quad$ Hossein Arefanian $^{\mathrm{a}} \quad$ Ajit Wilson $^{\mathrm{a}}$ \\ Shihab Kochumon ${ }^{a}$ Reeby Thomas ${ }^{a}$ Steve Shenouda ${ }^{a}$ Fahd Al-Mulla ${ }^{a, b}$ \\ Rasheed Ahmad ${ }^{\mathrm{a}}$ Sardar Sindhu ${ }^{\mathrm{b}}$ \\ aDepartment of Microbiology \& Immunology, Dasman Diabetes Institute (DDI), Dasman, Kuwait, \\ ${ }^{\mathrm{b}}$ Animal and Imaging Core Facility, Dasman Diabetes Institute (DDI), Dasman, Kuwait
}

\section{Key Words}

TLR2 - TLR4 - PBMC • Oxidative stress - Hydrogen peroxide - Reactive oxygen species • Metabolic inflammation

\begin{abstract}
Background/Aims: Innate immune toll-like receptors (TLRs) are emerging as nutrient sensors. Oxidative stress in the adipose tissue in obesity acts as a critical early trigger of altered pathophysiology. TLR2/TLR4 adipose upregulation has been associated with insulin resistance in humans; however, it remains unclear whether oxidative stress can modulate expression of TLR2/4 and related immune-metabolic regulators (IRF3/5) in immune cells. We, therefore, assessed their expression along with proinflammatory cytokines in the human PBMC following induction of oxidative stress. Methods: PBMC were isolated from blood of healthy donors using Ficoll-Paque method and cells were treated with $\mathrm{H}_{2} \mathrm{O}_{2}$ to induce oxidative stress. ROS was measured by DCFH-DA assay. Target gene and protein expression was determined using real-time RT-PCR and flow cytometry/confocal microscopy, respectively. TLR2/4 expression by $\mathrm{H}_{2} \mathrm{O}_{2}$ in presence of ROS-inhibitors or leptin/LPS/fatty acids was also assessed. Expression of phosphorylated/total ERK1/2, c-Jun, p38, and NF-KB was determined by western blotting. The data (mean \pm SEM) were compared using unpaired student's $t$-test or ANOVA; all P-values $<0.05$ were considered significant. Results: TLR2/4 mRNA/protein expression was elevated by oxidative stress in PBMC compared to controls $(\mathrm{P}<0.001)$. This induction was abrogated by apocynin/ $\mathrm{N}$-acetyl cysteine treatments $(\mathrm{P}<0.01) . \mathrm{H}_{2} \mathrm{O}_{2}$-induced $T L R 2 / 4$ gene expression was further enhanced by leptin, LPS, oleate, or palmitate $(P<0.05)$. Oxidative stress also promoted expression of IRF3/5 and proinflammatory cytokines including IFN- $\gamma, \mathrm{IL}-1 \beta, \mathrm{IL}-6, \mathrm{TNF}-\alpha$, and


MCP-1/CCL2. This oxidative stress in PBMC involved MAPK/NF-KB dependent signaling. Conclusion: Taken together, oxidative stress upregulates expression of TLR2/4, IRF3/5 and signature proinflammatory cytokines in PBMC, involving MAPK/NF-KB dependent signaling, all of which may have implications for metabolic inflammation.

(C) 2019 The Author(s). Published by Cell Physiol Biochem Press GmbH\&Co. KG

\section{Introduction}

The pathogen- and nutrient-sensing toll-like receptors (TLRs), also called pattern recognition receptors, are evolutionarily conserved in most species. These transmembrane proteins play a key role in the initiation of innate immune responses against microbial pathogens or against danger-associated molecular patterns that are expressed during cellular stress, malignancy, or viral infection [1]. The TLR family in mammals is so far known to comprise of 13 members (11 members in humans) [2]. TLRs are characterized by an extracellular leucine-rich repeat domain that engages in ligand recognition and a cytoplasmic Toll/IL-1 receptor (TIR) domain that activates downstream signaling (except TLR3) through myeloid differentiation (MyD)-88 factor, IL1R-associated kinases (IRAK1, IRAK4), tumor necrosis factor receptor-associated factor (TRAF)-6, and IкB kinase complex $[3,4]$. Activation of these adaptor proteins stimulates multiple signaling cascades including extracellular signal-regulated kinase (ERK), c-Jun N-terminal kinase (JNK), p38 mitogenactivated protein kinase (MAPK), and nuclear factor $\kappa B(\mathrm{NF}-\kappa \mathrm{B})$. The activation of these signaling pathways results in the upregulation of diverse inflammatory mediators such as $\mathrm{T}_{\mathrm{H}} 1$ cytokines, chemokines, and adhesion molecules, all of which play contributory roles to promote inflammation [5].

In addition to their well-established role in innate immunity, TLRs are also involved in the pathogenesis of several noninfectious chronic inflammatory conditions such as asthma, cancer, rheumatoid arthritis, inflammatory bowel disease, obesity, and type- 2 diabetes (T2D) [6-9]. In obesity, white adipose tissue stores excessive triglycerides and also secretes a myriad of inflammatory cytokines/chemokines (TNF- $\alpha$, IL-6, IFN- $\gamma$, MCP-1/CCL2, RANTES/ CCL5) as well as adipokines (leptin, resistin, visfatin), which lead to a state of chronic lowgrade sterile inflammation called metabolic inflammation [10, 11]. Thus, functionally, adipose tissue can be regarded as both a metabolic and immune organ; while histologically, it comprises of adipocytes and stromal vascular fraction i.e. extracellular matrix containing preadipocytes, fibroblasts, endothelial and immune cells including nearly the full spectrum of immune cell types as are found in the peripheral circulation [12]. Notably, in obese states, accumulation of excessive fat leads to increase in the number and activity of certain immune cell types (especially M1 macrophages, T/B lymphocytes, neutrophils, NK and NKT cells, and mast cells) while reductions in others (eosinophils, M2 macrophages, $\mathrm{T}_{\mathrm{H}} 2$ cells, iNKT cells and IL-10 producing FoxP3+ T regulatory cells), together with decreased expression of homeostatic protective factors (adiponectin, nitric oxide, or protective prostaglandins) [13]. This imbalance of immune cell homeostasis in the white adipose tissue is the forerunner of the development of metabolic inflammation.

The enhanced metabolic activity and energy demand in the white adipose tissue in obesity require additional supply of oxygen and nutrients which leads to neovascularization in fat tissue over time [14]. Thus, oxidative stress and redox state of adipose tissue are the critical initial triggers for the pathobiological changes associated with metabolic syndrome [15]. The adipose tissue microenvironment i.e. adipokines and hypoxia may contribute to the recruitment and phenotypic switch in immune cells. Previously, we and others have shown the upregulated expression of TLR2 and TLR4 in immune cells and adipose tissue in obesity/T2D or metabolic syndrome $[16,17]$. Increased TLR2/4 expression in obesity has been associated with metabolic inflammation and insulin resistance as the endotoxin (LPS) and free fatty acids (especially palmitate) act as TLR2/4 agonists and trigger the TLRdownstream inflammatory pathways [18-20]. In addition to TLR2/4, interferon regulatory factor (IRF)-3 and -5 are also emerging as immunometabolic regulators or stress sensors. 


\section{Cellular Physiology Cell Physiol Biochem 2019;53:1-18 \\ \begin{tabular}{c|c|c|} 
Dol: 10.33594/000000117 & O 2019 The Author(s). Published by \\
Cell Physiol Biochem Press GmbH\&Co.
\end{tabular} \\ Akhter et al.: Oxidative Stress Induces TLR2/4 Expression in Human PBMC}

IRFs are involved in TLR signaling through MyD88- as well as TRIF-dependent pathways [21]. It, however, remains unclear whether oxidative stress can modulate the expression of TLR2/4 in immune cells. Herein, we present the data showing that $\mathrm{H}_{2} \mathrm{O}_{2}$-mediated oxidative stress upregulates TLR2/4 expression and related metabolic regulators (IRF3/5) in the human peripheral blood mononuclear cells (PBMC) while the signaling mechanism involves MAPK/NF- $\mathrm{BB}$ pathways.

\section{Materials and Methods}

Blood collection, PBMC isolation, cell culture and stimulation

Peripheral blood samples (30mL each) were collected in EDTA vacutainer tubes following informed consent from healthy laboratory support staff at Dasman Diabetes Institute and PBMC were isolated using Ficoll-Hypaque density gradient method as described [22]. Briefly, blood samples were diluted (1:2) with RPMI 1640 medium (Gibco, Grand Island, NY, USA), gently layered over Ficoll gradient and centrifuged at $400 \times \mathrm{g}$ for $25 \mathrm{~min}$. The buffy coat cells collected at the interface were washed thrice with RPMI 1640 medium supplemented with $2 \%$ decomplemented fetal bovine serum (FBS; Gibco Life Technologies, Grand Island, NY, USA) and cells were resuspended in RPMI 1640 medium supplemented with 10 mM HEPES, $2 \mathrm{mM}$ L-glutamine, penicillin $(100 \mathrm{U} / \mathrm{mL})$, streptomycin $(100 \mu \mathrm{g} / \mathrm{mL})$, and $10 \% \mathrm{FBS}$. In culture assays, PBMC dispensed in triplicate wells of 12 -well plates $\left(10^{6}\right.$ cells $/ \mathrm{mL} /$ well $)$ were incubated for $2 \mathrm{~h}$ at $37^{\circ} \mathrm{C}$ in humidified incubator $\left(5 \% \mathrm{CO}_{2}\right)$ for conditioning. Later, cells were treated with hydrogen peroxide $\mathrm{CH}_{2} \mathrm{O}_{2}$; 9.8M, Cat. No. 822287.1000, Merck, USA) at a concentration of $10 \mathrm{mM}$ and cells were harvested after $10 \mathrm{~h}$ incubation, unless otherwise stated. For determining optimal concentration of $\mathrm{H}_{2} \mathrm{O}_{2}$, a time- and dosedependent assay was performed, with superoxide dismutase (SOD) induction and cytotoxicity as outcome measures, based on which it was found that $10 \mathrm{mM} \mathrm{H}_{2} \mathrm{O}_{2}$ concentration for $10 \mathrm{~h}$ induced a dose- and timedependent SOD activity in PBMC. Cell viability was assessed by trypan blue dye exclusion test and was found to be $>85 \%$ (data not shown).

In assays involving treatments with inhibitors of reactive oxygen species (ROS), PBMC were incubated with $100 \mu \mathrm{M}$ apocynin $(1 \mathrm{~h})$ or $5 \mathrm{mM} \mathrm{N}$-acetyl cysteine (NAC; $40 \mathrm{~min}$ ) in designated triplicate wells and treated with $\mathrm{H}_{2} \mathrm{O}_{2}(10 \mathrm{mM})$ for induction of oxidative stress. Cells were harvested after $10 \mathrm{~h}$, lysed in commercial RLT ${ }^{\mathrm{TM}}$ buffer $(350 \mu \mathrm{L})$ and stored at $-80^{\circ} \mathrm{C}$ until use. In assays involving treatments with factors related to obesity, PBMC dispensed in triplicate wells of 12 -well plates $\left(10^{6}\right.$ cells $/ \mathrm{mL} /$ well) were treated with leptin $(500 \mathrm{ng} / \mathrm{mL})$, LPS $(10 \mathrm{ng} / \mathrm{mL})$, oleate $(200 \mu \mathrm{M} / \mathrm{mL})$, or palmitate $(200 \mu \mathrm{M} / \mathrm{mL})$, with or without $\mathrm{H}_{2} \mathrm{O}_{2}(10 \mathrm{mM})$. Mock treatment included vehicle only. Cells were harvested after $10 \mathrm{~h}$ incubation, pellets were lysed in RLT buffer and stored at $-80^{\circ} \mathrm{C}$ until use.

\section{Real-time RT-PCR}

Total cellular RNA was purified using RNeasy kit and following the manufacturer's instructions (Qiagen, Valencia, CA., USA). Samples (1 $1 \mu \mathrm{g}$ each) were reverse transcribed into cDNA templates as recommended by the manufacturer (High Capacity cDNA Reverse Transcription kit; Applied Biosystems, CA, USA). For real-time RT-PCR, cDNA (50ng) was amplified (40 cycles) using TaqMan ${ }^{\circledR}$ Gene Expression MasterMix (Applied Biosystems, CA, USA) and gene-specific 20× TaqMan gene expression assays as follows: (TLR2) Hs02621280_s1; (TLR4) Hs00152939_m1; (IRF3) Hs01547283_m1; (IRF5) Hs00158114_m1; (IFN- $\gamma$ ) Hs00989291_m1; (IL-1ß) Hs01555410_m1; (IL-6) Hs00174131_m1; (TNF- $\alpha$ ) Hs00174128_m1; (MCP-1/ CCL2) Hs00234140_m1; and (GAPDH) Hs03929097_g1 (Applied Biosystems, CA, USA) containing forward/ reverse primers and target-specific TaqMan ${ }^{\circledR}$ minor groove binder (MGB) probe fluorescein amidite (FAM)labeled at 5' end and non-fluorescent quencher (NFQ)-MGB-labeled at 3' end and using 7500 Fast RealTime PCR System (Applied Biosystems, CA, USA). Each cycle involved the denaturation $\left(15 \mathrm{sec}\right.$ at $\left.95^{\circ} \mathrm{C}\right)$, annealing/extension $\left(1 \mathrm{~min}\right.$ at $60^{\circ} \mathrm{C}$ ) after activation of Uracil-DNA-glycosylase (UDG; $2 \mathrm{~min}$ at $50^{\circ} \mathrm{C}$ ) and AmpliTaq gold enzyme $\left(10 \mathrm{~min}\right.$ at $\left.95^{\circ} \mathrm{C}\right)$. GAPDH was used as internal control to normalize the individual sample differences. Target gene expression relative to control expression was calculated by using $2^{-\Delta \Delta c t}$ method. The relative mRNA expression was expressed as fold change with regard to average control gene expression taken as 1 . 


\section{Cellular Physiology Cell Physiol Biochem 2019;53:1-18 \\ and Biochemistry \begin{tabular}{l|l} 
DOl: 10.33594/000000117 & (c) 2019 The Author(s). Published by \\
Cell Physiol Biochem Press GmbH $\&$ Co.
\end{tabular} \\ Akhter et al.: Oxidative Stress Induces TLR2/4 Expression in Human PBMC}

\section{Flow cytometry}

PBMC $\left(10^{6} / \mathrm{mL} /\right.$ well) cultured in triplicate wells of 12 well plates, as described before, were treated with $10 \mathrm{mM} \mathrm{H}_{2} \mathrm{O}_{2}$ for $10 \mathrm{~h}$ whereas mock-treated cells served as control. In cell cultures for intracellular staining, Golgi protein transport was inhibited by adding $1 \mu \mathrm{L} /$ well Brefeldin-A (BFA) solution (1000×; Cat\# ab193369, Abcam, USA) at $3 \mathrm{~h}$ following cell treatments with $\mathrm{H}_{2} \mathrm{O}_{2}$ or vehicle. For extracellular staining, cells were harvested after a total incubation time of $10 \mathrm{~h}$, washed twice with PBS (containing $2 \%$ BSA and $0.2 \%$ sodium azide) and resuspended in $30 \mu \mathrm{L}$ staining buffer. Then, anti-human phycoerythrin (PE)-conjugated TLR2 (Cat\# NBP2-24909, NOVUS, USA) and fluorescein isothiocyanate (FITC)-conjugated TLR4 (Cat\# NBP100-56059, NOVUS, USA) antibodies were added, $5 \mu \mathrm{L}$ each. Cells were incubated on wet ice in dark for $30 \mathrm{~min}$ and mixed gently every $5 \mathrm{~min}$. Cells stained with similarly-labeled isotype-specific antibodies served as staining control. For intracellular staining, cells were harvested at $7 \mathrm{~h}$ following addition of BFA, washed/fixed using $250 \mu \mathrm{L}$ fixation solution per sample and incubated for 20 min on wet ice in dark. After fixation, cells were washed twice with $1 \times$ permeabilization buffer (Cat\# BD554714; BD Cytofix/Cytoperm ${ }^{\mathrm{TM}}$ Fixation/Permeabilization Solution Kit, BD Biosciences, USA) and then stained for 30 min on wet ice in dark with intermittent mixing every $5 \mathrm{~min}$. The staining antibodies included anti-human AF488-conjugated interferon regulatory factor (IRF)-3, (Cat\# IC4019G, R\&D, USA), PE-conjugated IRF5 (Cat\# IC4508P, R\&D, USA), allophycocyanin (APC)-conjugated IFN- $\gamma$ (Cat\# 554702, BD Biosciences, USA), FITC-conjugated IL-1 $\beta$ (Cat\# 11-7018-42 e-Biosciences, USA), PE-conjugated IL-6 (Cat\#12-7069-41, e-Biosciences, USA), FITCconjugated TNF- $\alpha$ (Cat\#340511, BD Biosciences, USA), and PE-conjugated MCP-1/CCL2 (Cat\#554666, BD Biosciences, USA), $5 \mu \mathrm{L}$ each. Cells stained with similarly-labeled isotype-specific antibodies served as staining control. After staining, cells were washed twice with $1 \times$ permeabilization buffer and analyzed by flow cytometry (FACSCanto II Flow Cytometer, Becton Dickinson, BD Biosciences, USA). Target protein expression was expressed, as appropriate, by mean fluorescence intensity (MFI) or staining index (SI) which was calculated as follows: SI = (Median of Experimental - Median of Mock) / (SD of Mock $\times 2$ ). The protein expression of IFN- $\gamma$, IL-1 $\beta$, IL-6, TNF- $\alpha$, and MCP-1 was compared (histogram overlays) for isotype control antibody, mock and $\mathrm{H}_{2} \mathrm{O}_{2}$ treatment using BD FACS DIVA software version 6.1.3.

\section{Intracellular ROS assay}

Induction of ROS following $\mathrm{H}_{2} \mathrm{O}_{2}$-mediated oxidative stress was assessed using commercial ROS assay kit (Cat. \#KP-06-003 BQC Kit, BioQueChem Inc.), based on the uptake of cell permeant 2'-7'dichlorofluorescein diacetate (DCFH-DA) fluorogenic probe. Following cell incubation with probe for $15 \mathrm{~min}$, DCFH-DA is hydrolyzed/deacetylated by cellular esterases into DCFH carboxylate anion which is later oxidized by ROS to yield a fluorescent product called 2'-7'dichlorofluorescein (DCF), measurable by flow cytometry, fluorescent microscopy or fluorimetry (excitation/emission spectra of $495 \mathrm{~nm} / 529 \mathrm{~nm})$. Briefly, PBMC $\left(10^{6}\right.$ cells $\left./ \mathrm{mL}\right)$ were treated with $\mathrm{H}_{2} \mathrm{O}_{2}(10 \mathrm{mM})$ for $10 \mathrm{~h}$. Later, cells were stained in culture media with $15 \mu \mathrm{M}$ DCFH-DA for $30 \mathrm{~min}$ at $37^{\circ} \mathrm{C}$ and analyzed (without washing) by flow cytometry. The final product DCF was excited using $488 \mathrm{~nm}$ laser and detected at $535 \mathrm{~nm}$.

\section{Confocal microscopy}

PBMC isolated from healthy donors' blood were washed and coated $\left(10^{6} \mathrm{cell} / \mathrm{mL}\right)$ on slides using cytospin method (500rpm for $3 \mathrm{~min}$ ). Cells were fixed in $4 \%$ formaldehyde, washed thrice in cold PBS, then permeabilized using $0.1 \%$ Triton X-100 and again washed three times in cold PBS. After blocking for $1 \mathrm{~h}$ in $1 \%$ bovine serum albumin, cells were incubated overnight at $4^{\circ} \mathrm{C}$ with primary antibodies including rabbit polyclonal anti-human TNF- $\alpha$ antibody (Abcam ${ }^{\circledR}$ ab9635) or rabbit polyclonal anti-human MCP-1/CCL2 antibody (Abcam ${ }^{\circledR}$ ab9669). Later, cells were washed $3 \times$ in PBS containing $0.05 \%$ Tween and incubated for $1 \mathrm{~h}$ with secondary goat anti-rabbit antibodies including, respectively, Alexa Fluor 647-conjugated antibody (Abcam ${ }^{\circledR}$ ab150079; red fluorescence) or Alexa Fluor 488-conjugated antibody (Abcam ${ }^{\circledR}$ ab150077; green fluorescence). After at least three washes in PBS, samples were finally treated with 4',6-diamidino2-phenylindole (DAPI; Vectashield, Vector Lab, H1500; counterstain in blue) and mounted with coverslips. Confocal images were analyzed using inverted Zeiss LSM710 AxioObsever microscope (Carl Zeiss, Gottingen, Germany) and Plan-Apochromat 63 x/1.40 oil DIC M27 objective lens. After laser excitation of samples (543nm HeNe laser and 405nm argon ion laser), optimized emission detection bandwidths were configured, and fluorescence intensity was calculated (Zeiss Zen 2010 software). 
Western blotting

PBMC in triplicate wells of 12 -well plates $\left(1 \times 10^{6}\right.$ cells $/ \mathrm{mL}$ per well $)$ were cultured in RPMI-1640 complete medium and treated with $\mathrm{H}_{2} \mathrm{O}_{2}(10 \mathrm{mM})$ while cells treated with vehicle only served as control. Samples were collected for analysis at $15 \mathrm{~min}, 30 \mathrm{~min}, 2 \mathrm{~h}$, and $4 \mathrm{~h}$ following incubation with $\mathrm{H}_{2} \mathrm{O}_{2}$. Incubation was not extended up to $10 \mathrm{~h}$ since optimal phosphorylation times of these signaling proteins are limited. Harvested samples were lysed using radioimmunoprecipitation assay (RIPA) Lysis and Extraction buffer (Cat\# 89900, Thermo Scientific, IL, USA) containing 25mM Tris.HCl pH 7.6, $150 \mathrm{mM} \mathrm{NaCl}, 1 \%$ NP-40, $1 \%$ sodium deoxycholate, and $0.1 \%$ sodium dodecyl sulfate (SDS). Cell lysates were clarified by centrifugation (14000 rpm, $10 \mathrm{~min}$ ) and supernatants were collected. Protein concentration was measured using Quickstart

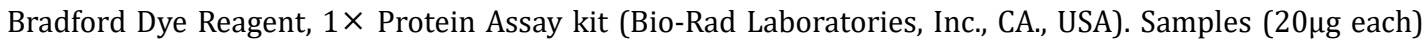
were mixed with loading buffer, heated at $95^{\circ} \mathrm{C}$ for $5 \mathrm{~min}$ and resolved by $12 \%$ SDS polyacrylamide gel electrophoresis (SDS-PAGE). Cellular proteins were transferred to Immuno-Blot polyvinylidene fluoride (PVDF) membrane (Bio-Rad Laboratories, USA) by electro blotting. The membranes were blocked with $5 \%$ non-fat milk in PBS for $1 \mathrm{~h}$, followed by overnight incubation with 1:1000 diluted primary antibodies

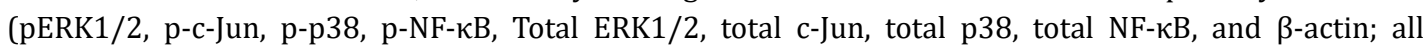
antibodies were purchased from Cell Signaling Technology Inc. USA). Blots were washed four times with Tris-buffered saline (TBS) and incubated for $2 \mathrm{~h}$ with horse radish peroxidase (HRP)-conjugated secondary antibody (Promega, Madison, WI, USA). Immunoreactive bands were developed using Amersham ECLPlus Western Blotting Detection System (GE Health Care, Buckinghamshire, UK) and visualized by Molecular Imager ${ }^{\circledR}$ VersaDoc ${ }^{\mathrm{TM}}$ MP Imaging Systems (Bio-Rad Laboratories, Hercules, CA., USA). Band intensities were measured using VersaDoc ${ }^{\mathrm{TM}}$ QuantityOne software (Bio-Rad Laboratories, Hercules, CA, USA). A total protein expression against respective phosphorylated protein represented loading control. Band intensity data were normalized by calculating ratios of phosphorylated over respective total proteins. Phosphorylation induction (fold change) in $\mathrm{H}_{2} \mathrm{O}_{2}$-treated samples was assessed by comparing with mock-treated control taken as 1.

\section{Statistical analysis}

Data were expressed as mean \pm SEM values and statistical analysis was performed using GraphPad Prism software (La Jolla, CA., USA). Unpaired Student $t$-test and analysis of variance (ANOVA) Bartlett's test, with Dunnett's or Tukey's tests as applicable, were used to compare group means. All P-values $<0.05$ were considered as statistically significant.

\section{Results}

Oxidative stress upregulates expression of TLR2 and TLR4 receptors in PBMC

We asked whether the oxidative stress induced by $\mathrm{H}_{2} \mathrm{O}_{2}$ treatment in vitro could modulate the expression of TLR2 and TLR4 innate immune and nutrient sensor receptors in the PBMC. To this end, our data show that TLR2 and TLR4 gene expression was significantly upregulated in PBMC following induction of oxidative stress as compared to mock-treated controls (TLR2 fold change: $6.63 \pm 0.94$ vs. $1.0 \pm 0.01 \&$ TLR 4 fold change: $4.11 \pm 0.25$ vs. $1.0 \pm 0.02)(\mathrm{P}<0.001$; Fig. 1A). As expected, TLR2 and TLR4 protein expression was accordingly enhanced in PBMC after $\mathrm{H}_{2} \mathrm{O}_{2}$ treatment for oxidative stress compared to mock-treated control (TLR2 MFI: $412.3 \pm 8.4$ vs. $239.7 \pm 3.7$ \& TLR4 MFI: $374.0 \pm 3.1$ vs. $116.7 \pm 1.2)(\mathrm{P}<0.0001$; Fig. $1 B)$. Surface expression of TLR2 ( $\mathrm{SI}=3.03$ ) and TLR4 ( $\mathrm{SI}=1.45)$ in PBMC treated with $\mathrm{H}_{2} \mathrm{O}_{2}$, mock (vehicle only), and isotype antibody control is also compared by histogram overlays (Fig. 1C \& 1D). Overall, good agreement was found between gene and protein expression of both TLR2 $(\mathrm{r}=0.80, \mathrm{P}=0.05)$ and TLR4 ( $\mathrm{r}=0.83, \mathrm{P}=0.04)$ (Supplementary Fig. S1 - for all supplemental material see www.cellphysiolbiochem.com). 

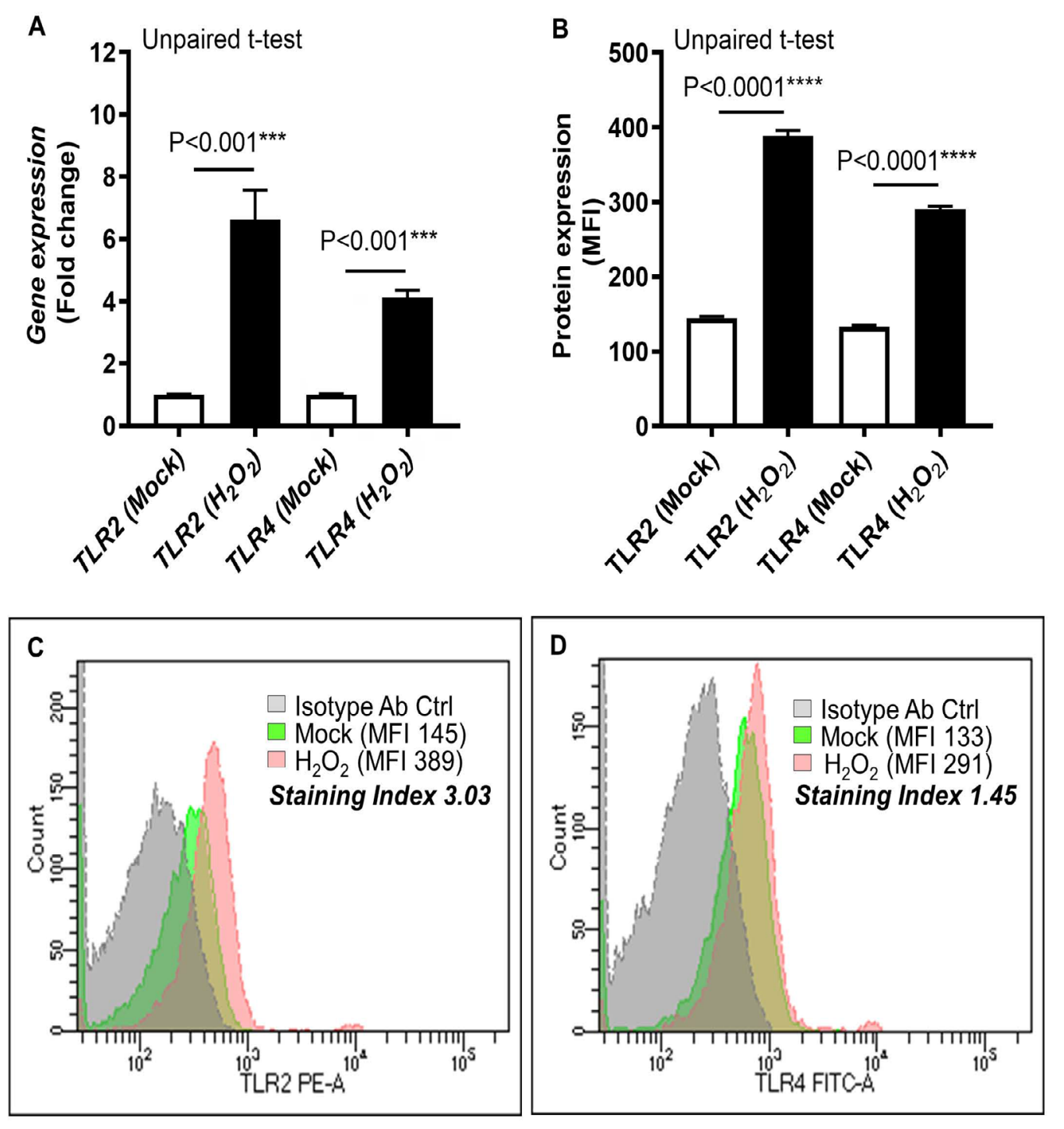

Fig. 1. Oxidative stress promotes the expression of TLR2 and TLR4 in PBMC. Peripheral blood mononuclear cells (PBMC) isolated from healthy individuals were cultured $\left(10^{6} \mathrm{cells} / \mathrm{mL} /\right.$ well $)$ in triplicate wells of 12 -well plates and incubated for $10 \mathrm{~h}$ with $\mathrm{H}_{2} \mathrm{O}_{2}(10 \mathrm{mM})$ or vehicle (mock). Total RNA was extracted from harvested cells using RNeasy kit following the manufacturer's instructions and TLR2/4 gene expression was assessed using real-time RT-PCR as described in materials and methods. At the same time, harvested samples were also stained to determine TLR2/4 receptor expression by flow cytometry. The data (mean \pm SEM) obtained from 5 independent determinations with similar results show the increased: (A) mRNA expression of TLR2 $(6.63 \pm 0.94$ fold) and TLR4 (4.11 \pm 0.25 fold) $(\mathrm{P}<0.001)$; and $(\mathrm{B})$ protein expression (MFI) of TLR2 (412.3 \pm 8.4$)$ and TLR4 (374.0 \pm 3.1$)(\mathrm{P}<0.0001)$ in $\mathrm{H}_{2} \mathrm{O}_{2}$-treated PBMC compared to respective controls (mock).

$\mathrm{H}_{2} \mathrm{O}_{2}$-induced TLR2/TLR4 gene expression is ROS-dependent and is abrogated by ROS inhibitors

To see if $\mathrm{H}_{2} \mathrm{O}_{2}$ treatment induced ROS, PBMC were stained using DCFH-DA fluorogenic probe to measure intracellular ROS activity and the representative histogram overlay shows that $\mathrm{H}_{2} \mathrm{O}_{2}$ treatment promoted the intracellular ROS activity compared to mock ( $\mathrm{SI}=18.13$; Fig. $2 \mathrm{~A}$ ). Next, to see whether oxidative stress driven TLR2/TLR4 expression was ROSdependent, PBMC were treated with $\mathrm{H}_{2} \mathrm{O}_{2}$ in the presence or absence of ROS inhibitors such 


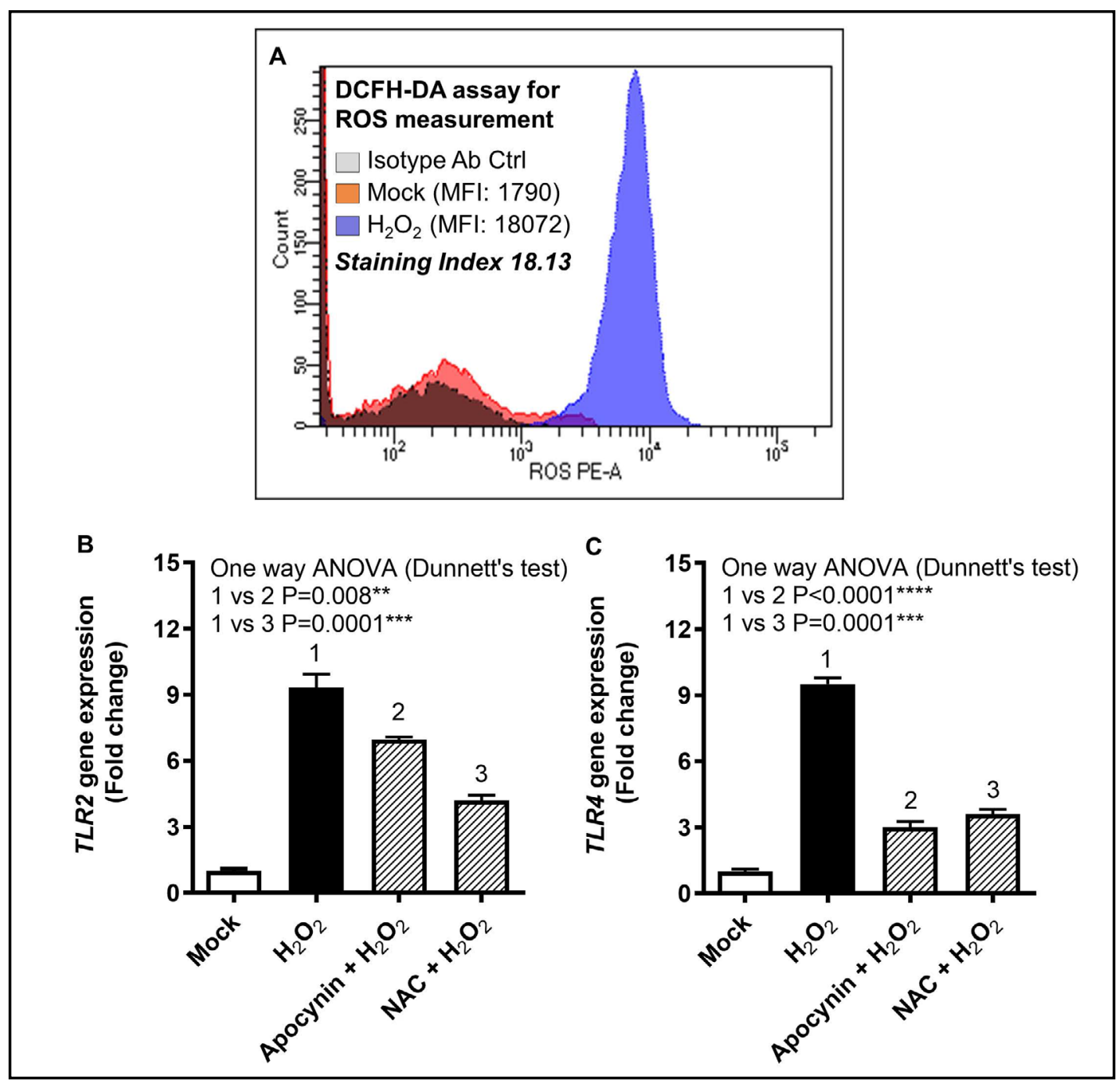

Fig. 2. TLR2/4 gene expression is ROS-dependent and is abrogated by ROS inhibitors. PBMC isolated from three healthy individuals were cultured $\left(10^{6}\right.$ cells $/ \mathrm{mL} /$ well $)$ in triplicate wells of 12 -well plates and incubated for $10 \mathrm{~h}$ with $\mathrm{H}_{2} \mathrm{O}_{2}(10 \mathrm{mM})$ or vehicle only (mock). Intracellular ROS activity was measured using DCFH-DA assay. (A) The representative data from 3 independent determinations show the enhanced intracellular ROS activity in $\mathrm{H}_{2} \mathrm{O}_{2}$ - treated cells compared to mock (SI=18.13). In other experiments, PBMC were treated with ROS inhibitors/anti-oxidants as well as $\mathrm{H}_{2} \mathrm{O}_{2}$ for induction of oxidative stress. Total RNA was extracted, and TLR2/4 gene expression was assessed using real-time RT-PCR as described in materials and methods. The data (mean \pm SEM) obtained from 5 independent determinations with similar results show the reduced gene suppression of: (B) TLR2 in cells treated with apocynin $+\mathrm{H}_{2} \mathrm{O}_{2}(6.97 \pm 0.12$ fold, $\mathrm{P}=0.008)$ or $\mathrm{N}$-acetyl cysteine $+\mathrm{H}_{2} \mathrm{O}_{2}(4.2 \pm 0.23$ fold, $\mathrm{P}=0.0001)$; and (C) TLR4 in cells treated with apocynin $+\mathrm{H}_{2} \mathrm{O}_{2}(3.00 \pm 0.27$ fold, $\mathrm{P}<0.0001)$ or $\mathrm{N}$-acetyl cysteine $+\mathrm{H}_{2} \mathrm{O}_{2}(3.6 \pm 0.21$ fold, $\mathrm{P}=0.0001)$ compared to respective controls treated with $\mathrm{H}_{2} \mathrm{O}_{2}$ alone. 
as apocynin and NAC. To this end, our data show that apocynin or NAC suppressed the $\mathrm{H}_{2} \mathrm{O}_{2}$ induced gene expression of TLR2 (Apocynin $+\mathrm{H}_{2} \mathrm{O}_{2}$ : $\quad 6.97 \pm 0.12$ fold $\mathrm{P}=0.008 ; \quad \mathrm{NAC}+\mathrm{H}_{2} \mathrm{O}_{2}$ : $4.2 \pm 0.23$ fold $\mathrm{P}=0.0001 ; \mathrm{H}_{2} \mathrm{O}_{2}$ : $9.33 \pm 0.60$ fold; Fig. 2B) and TLR4 (Apocynin $+\mathrm{H}_{2} \mathrm{O}_{2}: 3.00 \pm 0.27$ fold $\mathrm{P}<0.0001 ; \mathrm{NAC}+\mathrm{H}_{2} \mathrm{O}_{2}: 3.6 \pm 0.21$ fold $\mathrm{P}=0.0001 ; \mathrm{H}_{2} \mathrm{O}_{2}: 9.50 \pm 0.29$ fold; Fig. 2C).

\section{TLR2 and TLR4 gene expression is further promoted by synergy between oxidative stress and obesity-related factors \\ In view of the emerging} role of innate immune TLRs as metabolic sensors in obesity, we asked if pathophysiological factors associated with obesity/ T2D such as endotoxin (LPS), free fatty acids (palmitate/oleate), and leptin (a satiety hormone) could amplify the effect of oxidative stress and further promote TLR2/TLR4 expression. To this effect, our data show that $\mathrm{H}_{2} \mathrm{O}_{2}$-induced TLR2 gene expression in PBMC was further augmented in presence of each of leptin (41.53 \pm 1.34 fold $P=0.01$ ), LPS $(39.50 \pm 3.75$ fold $P=0.03)$, oleate $(40.27 \pm 1.18$ fold $\mathrm{P}=0.02)$, and palmitate $(45.10 \pm 1.07$ fold $\mathrm{P}=0.001)$ compared to TLR2 expression induced by $\mathrm{H}_{2} \mathrm{O}_{2}$ alone $(31.0 \pm 0.35$ fold) (Fig. $3 \mathrm{~A})$. Likewise, $\quad \mathrm{H}_{2} \mathrm{O}_{2}$-induced TLR4 gene expression in PBMC was also enhanced by each of leptin (19.50 \pm 1.04 fold $P=0.0005)$, LPS $(18.40 \pm 0.64$ fold $\mathrm{P}=0.002)$, oleate (17.78 \pm 0.06 fold $\mathrm{P}=0.005)$, and palmitate $(21.90 \pm 1.10$ fold $\mathrm{P}<0.0001$ ) compared to TLR4 expression induced by $\mathrm{H}_{2} \mathrm{O}_{2}$ alone (13.0 \pm 0.58 fold) (Fig. 3B).

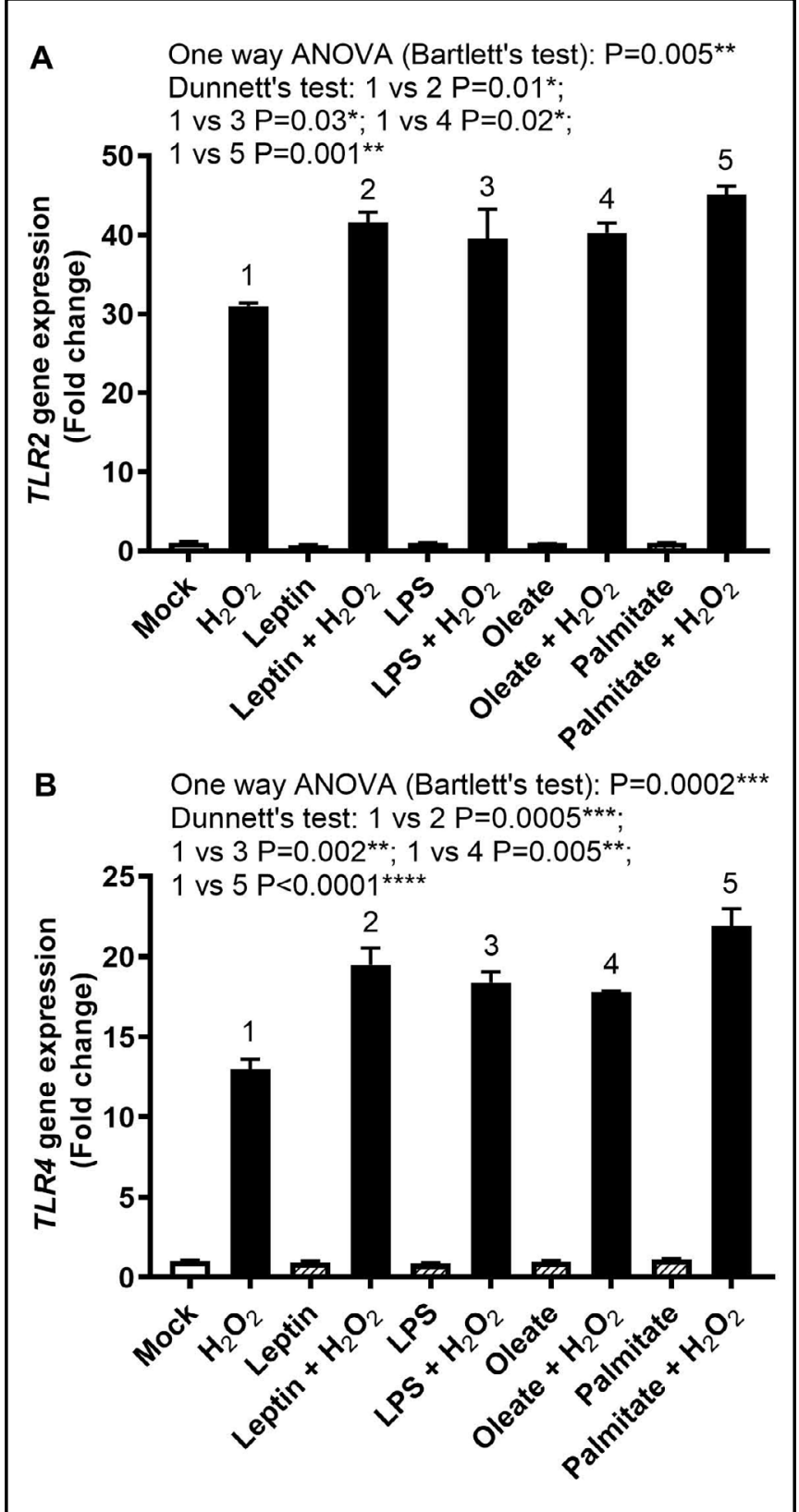

Fig. 3. TLR $2 / 4$ gene expression is enhanced by the synergy between oxidative stress and obesity-associated factors. PBMC were incubated with leptin, LPS, oleate, or palmitate, with or without oxidative stress $\left(\mathrm{H}_{2} \mathrm{O}_{2}\right)$. Total RNA was extracted, and TLR2/4 gene expression was assessed by real-time RT-PCR as described in materials and methods. The data (mean \pm SEM) obtained from 5 independent determinations with similar results show significant upregulation of: (A) TLR2 expression in cells treated with leptin $+\mathrm{H}_{2} \mathrm{O}_{2}(41.53 \pm 1.34$ fold $), \mathrm{LPS}+\mathrm{H}_{2} \mathrm{O}_{2}(39.50 \pm 3.75$ fold), oleate $+\mathrm{H}_{2} \mathrm{O}_{2} \quad(40.27 \pm 1.18$ fold $)$, or palmitate $+\mathrm{H}_{2} \mathrm{O}_{2}$ (45.10 \pm 1.07 fold); and (B) TLR4 expression in cells treated with leptin $+\mathrm{H}_{2} \mathrm{O}_{2} \quad\left(19.50 \pm 1.04\right.$ fold), $\mathrm{LPS}+\mathrm{H}_{2} \mathrm{O}_{2}$ (18.40 \pm 0.64 fold), oleate $+\mathrm{H}_{2} \mathrm{O}_{2}\left(17.78 \pm 0.06\right.$ fold), or palmitate $+\mathrm{H}_{2} \mathrm{O}_{2}(21.90 \pm 1.10$ fold) compared to respective controls treated with $\mathrm{H}_{2} \mathrm{O}_{2}$ alone. 

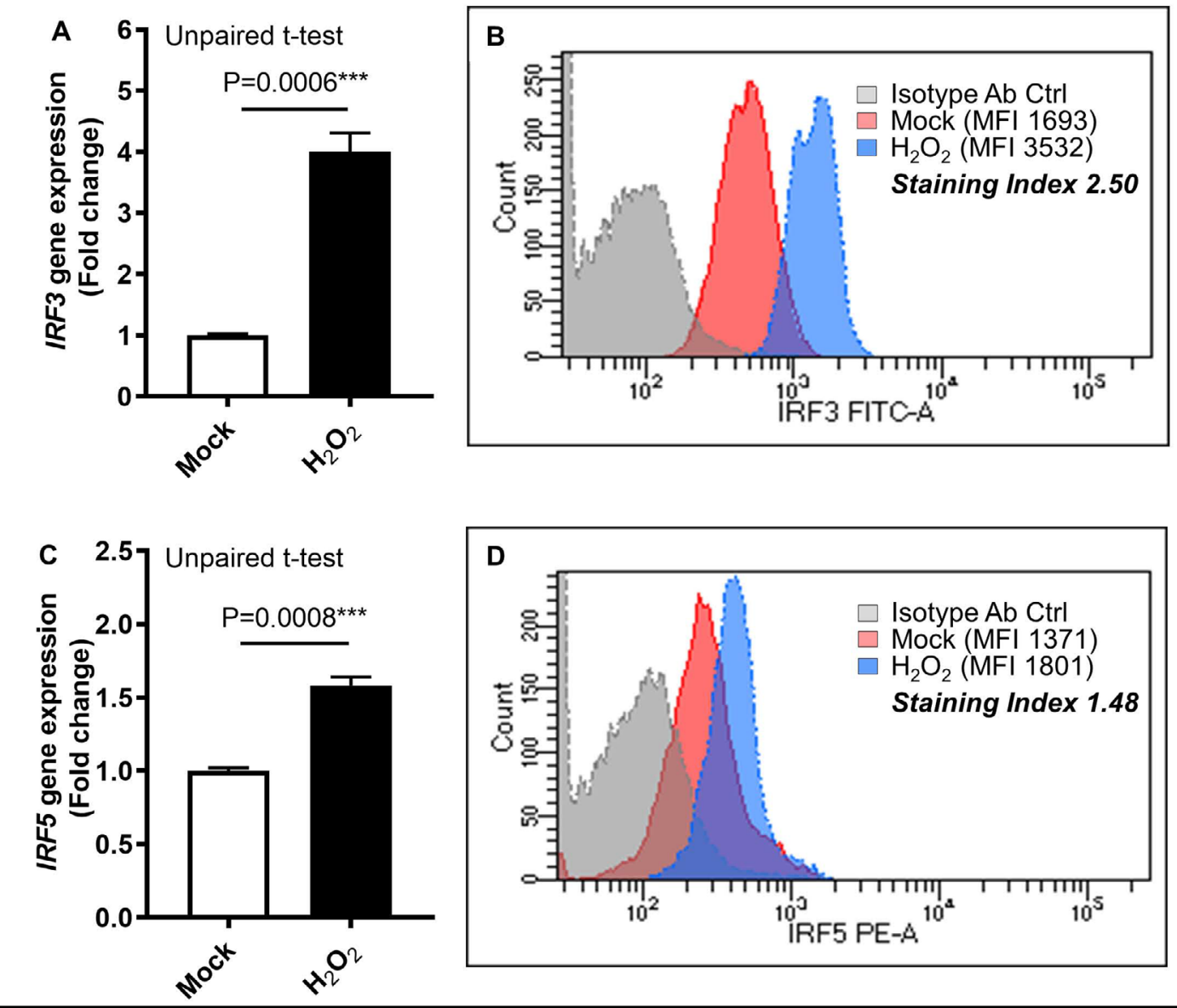

Fig. 4. Oxidative stress promotes the expression of IRF3 and IRF5. PBMC were treated with $\mathrm{H}_{2} \mathrm{O}_{2}$ for induction of oxidative stress or with vehicle (mock). Total RNA was extracted, and IRF3/5 gene expression was determined using real-time RT-PCR as described in materials and methods. At the same time, harvested cells were also stained intracellularly to assess the IRF3/5 protein expression (Staining Index) by flow cytometry. The data (mean $\pm \mathrm{SEM}$ ) obtained from 5 independent determinations with similar results show the increased IRF3 expression $(\mathrm{P}<0.05)$ in $\mathrm{H}_{2} \mathrm{O}_{2}$-treated PBMC at: $(\mathrm{A})$ mRNA $(4.0 \pm 0.31$ fold); and (B) protein ( $\mathrm{SI}=2.50$ ) levels compared to respective controls (mock). Similarly, $\mathrm{H}_{2} \mathrm{O}_{2}$ treatment enhanced the IRF5 expression $(\mathrm{P}<0.05)$ in $\mathrm{PBMC}$ at: $(\mathrm{C})$ mRNA $(1.60 \pm 0.06$ fold $)$; and $(\mathrm{D})$ protein $(\mathrm{SI}=1.48)$ levels compared to respective controls (mock).

\section{Oxidative stress promotes the expression of IRF3 and IRF5}

IRF3 and IRF5 are important transcriptional regulators of the innate and adaptive immunity and recent evidence suggests that TLR-associated pathogenic or stress responses also act as IRF activators. Therefore, we wanted to know if oxidative stress, in addition to upregulating the TLR2/4 expression, could also modulate the IRF3/IRF5 expression as both these transcriptional regulators have been implicated with metabolic stress sensing and inflammation. Our data show that $\mathrm{H}_{2} \mathrm{O}_{2}$ promoted the gene/protein expression of IRF3 (mRNA: $4.0 \pm 0.31$ fold vs. $1.0 \pm 0.02$ fold $\mathrm{P}=0.0006$; Protein: $\mathrm{SI}=2.50$ ) (Fig. $4 \mathrm{~A}, \mathrm{~B}$ ) and IRF5 (mRNA: $1.60 \pm 0.06$ fold vs. $1.0 \pm 0.02$ fold $\mathrm{P}=0.0008$; Protein: $\mathrm{SI}=1.48$ ) as compared to mock (Fig. 4 C, D). Besides, as shown in Supplementary Fig. S2, gene expression of MyD88 which is the TLR downstream adaptor and FOXO1 which is a key regulator of cellular stress and nutrient/energy homeostasis was also upregulated by oxidative stress $\left(M_{y} D 88_{\text {H2O2 }}: 1.63 \pm 0.06\right.$

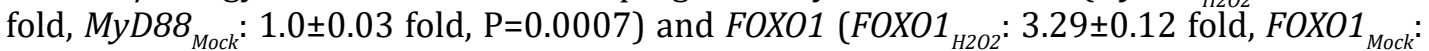
$1.0 \pm 0.01$ fold, $\mathrm{P}<0.0001$ ). 


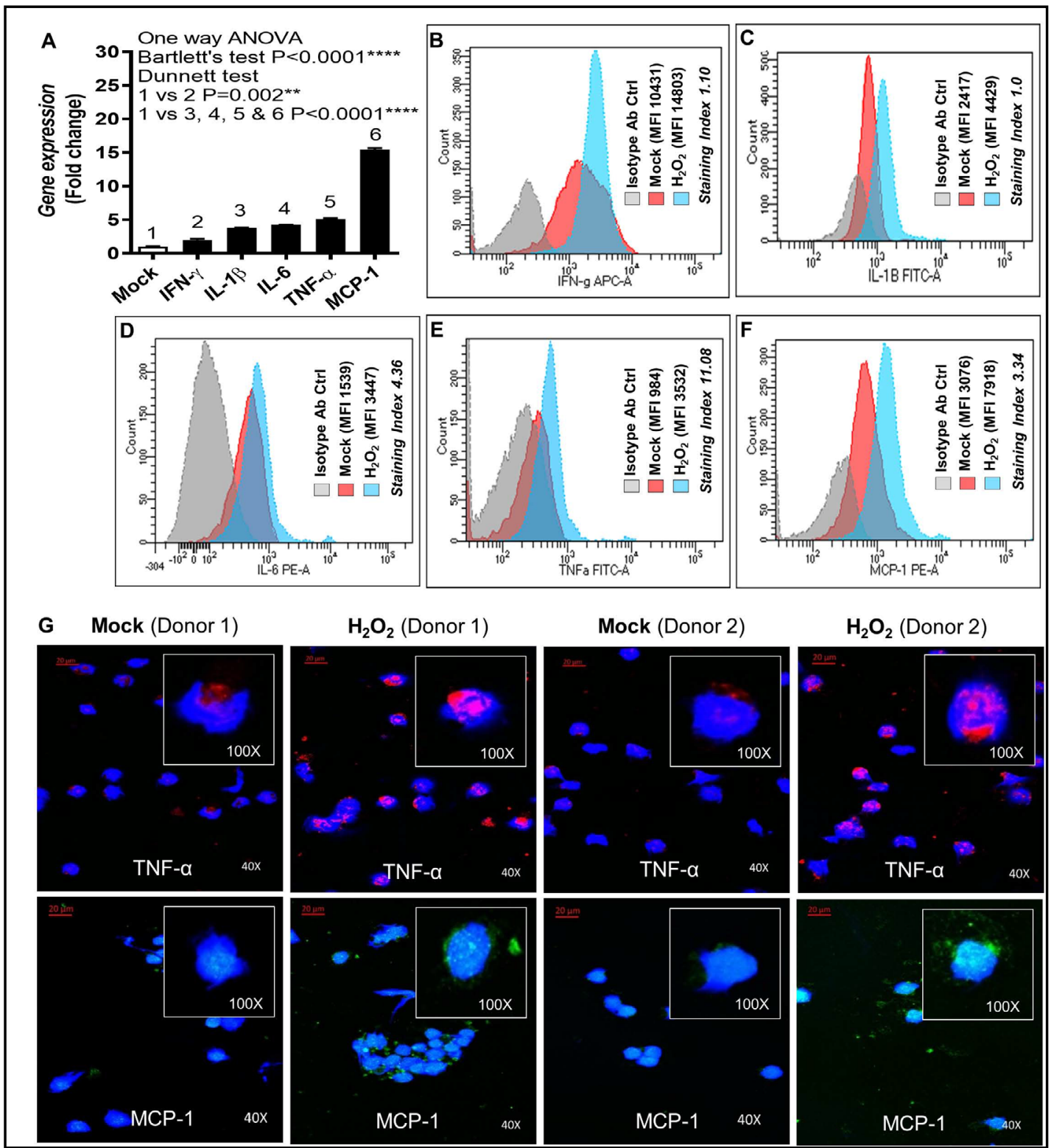

Fig. 5. Oxidative stress promotes the expression of proinflammatory cytokines/chemokine. PBMC were treated with $\mathrm{H}_{2} \mathrm{O}_{2}$ for induction of oxidative stress or with vehicle (mock). Total RNA was extracted and IFN- $\gamma$, IL-1 $\beta$, IL-6, TNF- $\alpha$, and MCP-1 gene expression was determined using real-time RT-PCR as described in materials and methods. At the same time, harvested cells were also stained intracellularly to assess protein expression of these cytokines/chemokine by flow cytometry (SI) and/or confocal microscopy. (A) The data (mean \pm SEM) obtained from 5 independent determinations with similar results show that $\mathrm{H}_{2} \mathrm{O}_{2}$ treatment promoted mRNA expression of IFN- $\gamma(2.0 \pm 0.21$ fold), IL-1 $\beta$ (3.81 \pm 0.02 fold), IL-6 (4.23 \pm 0.04 fold), TNF- $\alpha$ (5.10 \pm 0.18 fold), and MCP-1 (15.47 \pm 0.22 fold) compared to mock. As expected, oxidative stress also enhanced protein expression of (B) IFN- $\gamma$ (SI=1.10), (C) IL-1 $\beta$ (SI=1.0), (D) IL-6 (SI=4.36), (E) TNF- $\alpha$ (SI=11.08), and (F) MCP-1 (SI=3.34) compared to mock. (G) Confocal microscopy images (40× magnification; inset at $100 \times$ magnification) show the elevated TNF- $\alpha$ and MCP-1 expression in PBMC treated with $\mathrm{H}_{2} \mathrm{O}_{2}$ as compared to mock, two donors each. 


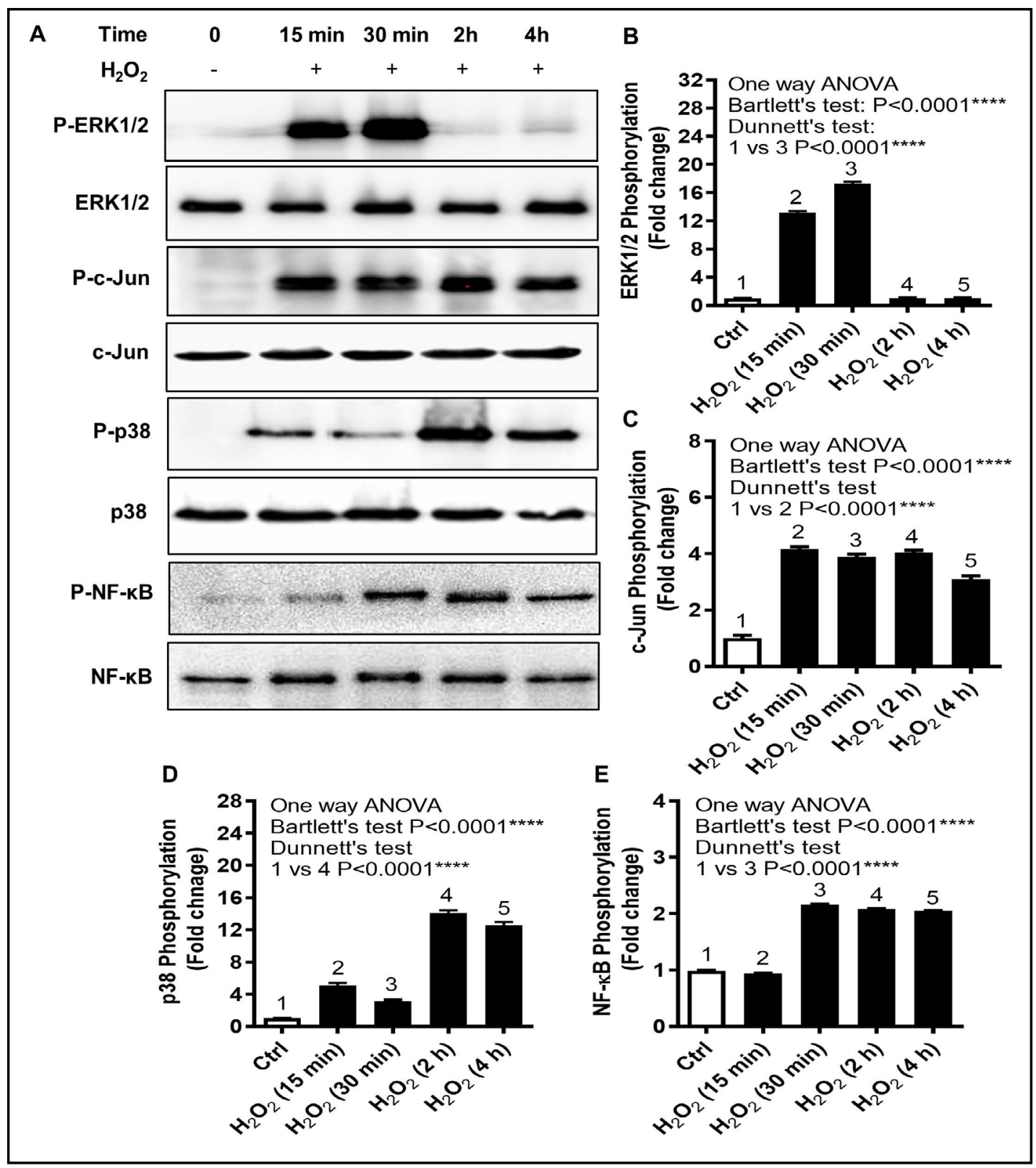

Fig. 6. $\mathrm{H}_{2} \mathrm{O}_{2}$-mediated oxidative stress involves MAPK/NF- $\kappa B$ dependent signaling. PBMC were treated with $\mathrm{H}_{2} \mathrm{O}_{2}$ for induction of oxidative stress or with vehicle (mock). Samples were collected at $15 \mathrm{~min}, 30 \mathrm{~min}, 2 \mathrm{~h}$, and $4 \mathrm{~h}$ time intervals following $\mathrm{H}_{2} \mathrm{O}_{2}$-treatment and extracted proteins were analyzed by western blotting as described in materials and methods to detect phosphorylated vs. total ERK1/2, c-Jun, p38, and NF- $\kappa B$. Incubation was not extended up to $10 \mathrm{~h}$ since optimal phosphorylation times of these signaling proteins are limited. (A) Western blots depict the expression of phosphorylated and total signaling proteins at 15 min, $30 \mathrm{~min}, 2 \mathrm{~h}$, and $4 \mathrm{~h}$ intervals following $\mathrm{H}_{2} \mathrm{O}_{2}$ treatment. Densitometry data (mean $\pm \mathrm{SEM}$ ) were used to calculate phosphorylated to total protein ratios. $\mathrm{H}_{2} \mathrm{O}_{2}$ induced the optimal phosphorylation of (B) ERK1/2 (17.32 \pm 0.17 fold), (C) c-Jun (4.20 \pm 0.05 fold), (D) p38 (14.13 \pm 0.19 fold), and (E) NF- $\kappa B(2.10 \pm 0.01$ fold) at $30 \mathrm{~min}, 15 \mathrm{~min}, 2 \mathrm{~h}$, and $30 \mathrm{~min}$, respectively, as compared to mock $(\mathrm{P}<0.0001)$. 


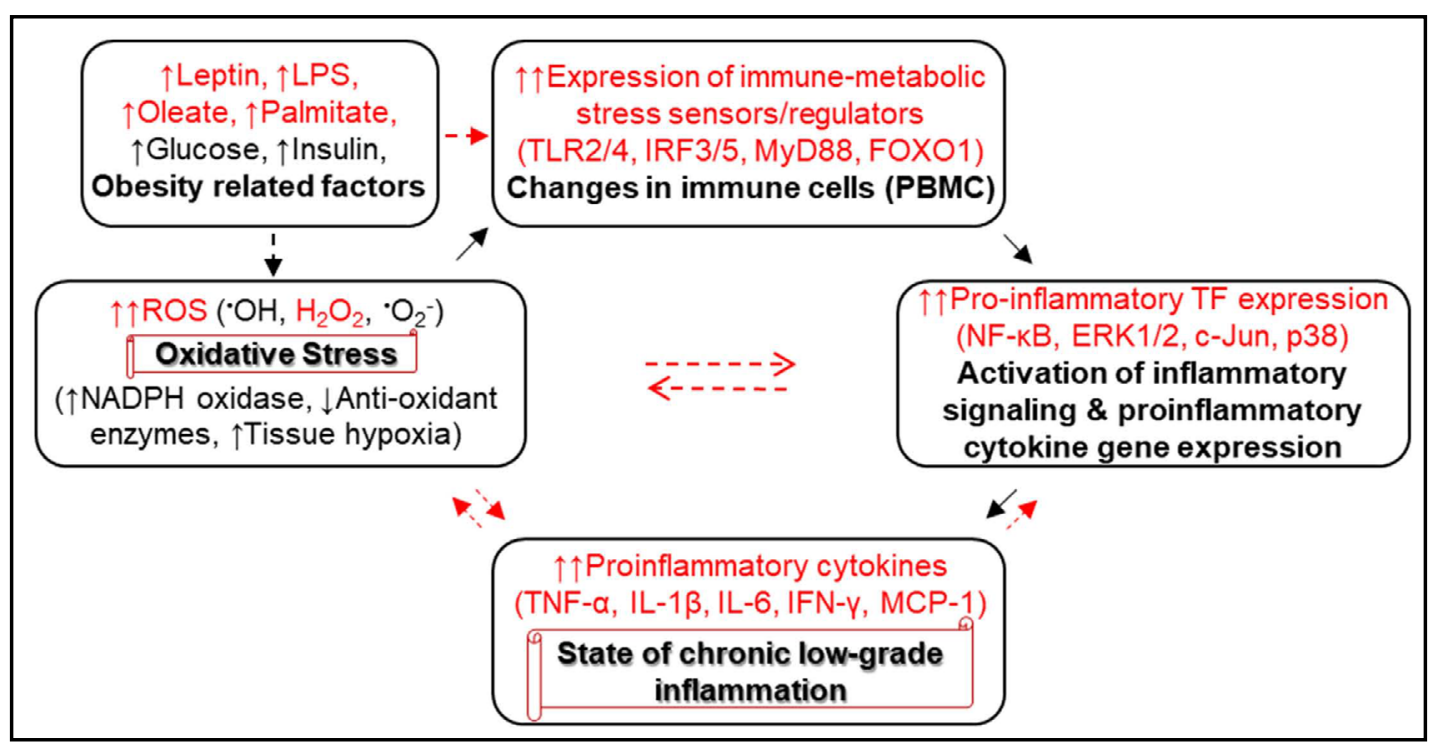

Fig. 7. A schematic illustration of the "feed forward model" of metabolic inflammation. The key findings (text in red) of our study support a suggested "feed forward model" (solid black arrows) of chronic lowgrade inflammation, also called metaflammation, in which, oxidative stress induced experimentally in human PBMC by $\mathrm{H}_{2} \mathrm{O}_{2}$ treatment drives the intracellular ROS which promotes the cellular expression of immunometabolic stress sensors or regulators including TLR2, TLR4, IRF3 and IRF5 (as well as MyD88 adaptor protein and FOXO1 metabolic regulator: presented as supplemental data). Our data show that TLR2/4 expression in PBMC can be further amplified by a cooperative interaction between ROS $\left(\mathrm{H}_{2} \mathrm{O}_{2}\right)$ and obesity-associated factors such as leptin, endotoxin (LPS), oleate, and palmitate (dashed black arrow). These changes are paralleled by activation of proinflammatory transcription factors related to NF- $\kappa \mathrm{B} / \mathrm{MAPK}$ signaling pathways, reminiscing a state of cellular activation to support inflammatory gene expression. Hence, ROS-stressed PBMC display the upregulated expression of signature proinflammatory cytokines/ chemokine including TNF- $\alpha$, IL-1 $\beta$, IL- 6, IFN- $\gamma$, and MCP- 1 which is consistent with a state of metabolic inflammation. As supported by other studies, proinflammatory cytokines such as TNF- $\alpha$, IL- $1 \beta$, and IFN- $\gamma$ can also elevate expression of the mitochondrial ROS to promote oxidative stress and metabolic inflammation. Note: Dashed red arrows represent other possible interactions in this metaflammatory loop, supported by existing evidence (the references are cited already in the text).

Oxidative stress drives the expression of proinflammatory cytokines/chemokine

We sought to know further implications of $\mathrm{H}_{2} \mathrm{O}_{2}$-induced oxidative stress in PBMC by determining expression of proinflammatory cytokines/chemokine. To this end, the data show that $\mathrm{H}_{2} \mathrm{O}_{2}$ treatment promoted the gene expression of signature proinflammatory cytokines/chemokine in PBMC including IFN- $\gamma(2.0 \pm 0.21$ fold; $\mathrm{P}=0.002), I L-1 \beta(3.81 \pm 0.02$ fold; $\mathrm{P}<0.0001), I L-6$ (4.23 \pm 0.04 fold; $\mathrm{P}<0.0001)$, TNF- $\alpha$ (5.10 \pm 0.18 fold; $\mathrm{P}<0.0001$ ), and MCP1 (15.47 \pm 0.22 fold; $\mathrm{P}<0.0001)$ as compared to mock (Fig. $5 \mathrm{~A})$. As expected, oxidative stress in PBMC also elevated protein expression of IFN- $\gamma(\mathrm{SI}=1.10), \mathrm{IL}-1 \beta$ (SI=1.0), IL-6 (SI=4.36), TNF- $\alpha$ (SI=11.08), and MCP-1 (SI=3.34) compared to mock (Fig. 5 B-F) $\mathrm{H}_{2} \mathrm{O}_{2}$-induced protein expression in PBMC was also confirmed by confocal microscopy (40× magnification, inset at 100x), shown herein for TNF- $\alpha$ and MCP-1, two donors each (Fig. 5G). TNF- $\alpha$ and MCP1 protein expression detected by confocal microscopy (expressed as MFI) is also shown graphically, comparing between $\mathrm{H}_{2} \mathrm{O}_{2}\left(\mathrm{MFI}_{\mathrm{TNF}-\alpha} 37.94 \pm 0.69\right.$; $\left.\mathrm{MFI}_{\mathrm{MCP}-1} 28.89 \pm 1.24\right)$ and mock $\left(\mathrm{MFI}_{\mathrm{TNF}-\alpha} 23.20 \pm 0.95 ; \mathrm{MFI}_{\mathrm{MCP}-1} 15.99 \pm 0.61\right.$ ) treatments (Supplementary Fig. S3).

$\mathrm{H}_{2} \mathrm{O}_{2}$-induced oxidative stress involves $M A P K / N F-\kappa B$ dependent signaling

Next, we asked which signaling mechanism was involved in $\mathrm{H}_{2} \mathrm{O}_{2}$-induced oxidative stress in PBMC. Densitometry data of western blots, shown in Fig. 6A, were used to calculate phosphorylated to total protein ratios. As compared to mock (1.0 \pm 0.01 fold), $\mathrm{H}_{2} \mathrm{O}_{2}$-induced 


\section{Cellular Physiology Cell Physiol Biochem 2019;53:1-18 \\ \begin{tabular}{ll|l}
\cline { 3 - 3 } and Biochemistry $10.33594 / 000000117$ & $\begin{array}{l}\text { Do } 2019 \text { The Author(s). Published by } \\
\text { Published online: } 5 \text { June 2019 }\end{array}$ & Cell Physiol Biochem Press GmbH\&Co. KG
\end{tabular} \\ Akhter et al.: Oxidative Stress Induces TLR2/4 Expression in Human PBMC}

phosphorylation of ERK1/2 (17.32 \pm 0.17 fold; Fig. $6 \mathrm{~B})$, c-Jun (4.20 \pm 0.05 fold; Fig. $6 \mathrm{C})$, p38 (14.13 \pm 0.19 fold; Fig. 6D), and NF- $\mathrm{B}(2.10 \pm 0.01$ fold; Fig. $6 \mathrm{E})$ was observed at $30 \mathrm{~min}, 15$ $\mathrm{min}, 2 \mathrm{~h}$, and $30 \mathrm{~min}$, respectively $(\mathrm{P}<0.0001)$. As supported by our key findings, a schematic illustration of the "feed forward model" of metabolic inflammation is also presented (Fig. 7).

\section{Discussion}

Toll-like receptors are emerging as a potential link between metabolism and inflammation. This study reports, for the first time to our knowledge, that the expression of TLR2 and TLR4 immunometabolic receptors is significantly upregulated by $\mathrm{H}_{2} \mathrm{O}_{2}$-induced oxidative stress in PBMC. Increased expression of TLR2 and TLR4 innate immune receptors has been reported in the adipose tissue in obesity/T2D [16, 23, 24], both in diabetic patients and animal models $[25,26]$. Nevertheless, it remains unclear which factor(s) may lead to changes in the TLR2/4 expression in obesity/T2D. Both human and animal studies have shown an association between hyperglycemia and upregulation of TLR2/TLR4 [27, 28]. However, during the initial stages of obesity, inadequate vascularization in the expanding adipose tissue leads to a milieu of hypoxia-induced oxidative stress which precedes hyperglycemia and insulin resistance. We, therefore, asked whether oxidative stress induction could upregulate the TLR2/TLR4 expression in PBMC. Herein, we report that $\mathrm{H}_{2} \mathrm{O}_{2}$-induced oxidative stress promotes the gene/protein expression of TLR2/4 in PBMC. $\mathrm{H}_{2} \mathrm{O}_{2}$ is produced in vivo by inflammatory and vascular cells and it gets engaged in oxidative stress mechanisms at organismal level for being the most stable and long-lasting component of ROS [29]. Our results showing the TLR2/4 upregulation by oxidative stress are consistent, at least in part, with our previous study showing similar changes in the TLR10 expression in THP-1 human monocytic cells [30].

Our data further show that $\mathrm{H}_{2} \mathrm{O}_{2}$ exposure induces/promotes the intracellular ROS in PBMC. As expected, TLR2/4 expression was potentially abrogated when cells were exposed to $\mathrm{H}_{2} \mathrm{O}_{2}$ in presence of an antioxidant (NAC) or a ROS inhibitor (apocynin). $\mathrm{H}_{2} \mathrm{O}_{2}$ treatment compromises the intrinsic antioxidant potential of cells by blunting catalase activity and results in oxidative stress due to ROS accumulation. Consistent with results of our in vitro study, a pervious study showed TLR2/4 suppression by NAC administration in mice [31]. Apocynin by acting as a NADPH oxidase inhibitor prevents the formation of superoxide radical and alleviates oxidative stress which explains the TLR2/4 suppression in cells treated with this agent. In agreement with these findings, another study also demonstrated that treatments with apocynin or NAC reduced the TLR2/4 expression in human retinal endothelial cells [32]. Collectively, these studies support a role of oxidative stress in TLR2/4 induction or upregulation in human cells.

Obesity is associated with increased circulatory levels of leptin, LPS, palmitate, and oleate [33-36]. We next asked if these factors could amplify the effect of oxidative stress and further drive the expression of TLR2/4 in PBMC. Our data show that each of these agents could cooperatively enhance the effect of $\mathrm{H}_{2} \mathrm{O}_{2}$ treatment and promote TLR2/4 expression in PBMC. These data are corroborated, at least in part, by previous studies showing enhanced expression of TLRs in response to oxidative stress in presence of LPS, palmitate or other obesity-associated factors; increased TLR expression was further linked to inflammatory responses [37-40]. Such cooperative inflammatory mechanisms could explain the diverse oxidative stress-driven pathologies related to obesity, T2D, or metabolic syndrome.

IRFs are poised at the crossroads of immunity, metabolism and disease. Emerging evidence indicates that IRFs play key roles as stress sensors in metabolism and as transcriptional regulators of adipogenesis [21, 41]. Many IRFs are regulated by posttranslational modifications downstream of pattern recognition receptors such as TLRs. IRFs, especially IRF1, IRF3, IRF5, IRF7, and IRF9 have been implicated in disease pathogenesis and development of several inflammatory conditions $[42,43]$. IRF3 has been related to metabolic stress, adipose inflammation and insulin resistance [44] while IRF5 is found to 


\section{Cellular Physiology Cell Physiol Biochem 2019;53:1-18 \\ \begin{tabular}{ll|l}
\cline { 3 - 3 } and Biochemistry $10.33594 / 000000117$ & $\begin{array}{l}\text { Do } 2019 \text { The Author(s). Published by } \\
\text { Published online: } 5 \text { June 2019 }\end{array}$ & Cell Physiol Biochem Press GmbH\&Co. KG
\end{tabular} \\ Akhter et al.: Oxidative Stress Induces TLR2/4 Expression in Human PBMC}

be positively modulated by obesity (our unpublished data). Therefore, we investigated if oxidative stress could promote the IRF3/IRF5 expression in PBMC. To this end, our data show that the mRNA and protein expression of both IRF3 and IRF5 was enhanced following $\mathrm{H}_{2} \mathrm{O}_{2}$ treatment. It implies that oxidative stress, in addition to upregulating expression of nutrient sensors (TLR2/4), could also promote the expression of metabolic stress sensors/ transcriptional regulators including IRF3/5 in PBMC. Alluding to TLR4-IRF3 connection, TLR4 downstream signaling activates IRF3 via TRAF3-TBK1 recruitment. While, several IRFs e.g. IRF-1, $-2,-4,-5,-6$, and -8 are involved in TLR signaling [45], IRF5 is activated by downstream signaling through several TLRs such as TLR-3, $-4,-5,-7,-8$, and $-9[46,47]$. Our data further show that $\mathrm{H}_{2} \mathrm{O}_{2}$ treatment led to the enhanced mRNA/protein expression of proinflammatory cytokines including IFN- $\gamma$, IL- $1 \beta$, IL- 6 , TNF- $\alpha$, and MCP- 1 in PBMC. Notably, these cells also display the increased surface expression of TLR2/4 which is further augmented by a cooperative interaction between oxidative stress and various TLR2/4 agonists such as LPS, palmitate, and oleate. This is in line with the paradigm that oxidative stress and proinflammatory processes are closely intertwined $[48,49]$. Our data showing elevated expression of IFN- $\gamma$, IL-1 $\beta$, IL- 6 , TNF- $\alpha$, and MCP- 1 in response to ROS induction/ oxidative stress are in agreement with other studies [50,51]; however, expression of these inflammatory proteins could have resulted from activation of the TLR2/4 downstream signaling cascades and not as a direct consequence of the induction of ROS/oxidative stress. Furthermore, induction of ROS by IFN- $\gamma$, IL-1 $\beta$, and TNF- $\alpha$ has also been documented [5254]. Taken together, ROS and proinflammatory cytokines can promote each other through a feed forward model of metaflammation, as depicted in our schematic illustration.

Regarding signaling mechanism(s) involved in $\mathrm{H}_{2} \mathrm{O}_{2}$-mediated ROS induction and/ or TLR2/4 upregulation in PBMC, phosphorylation of ERK1/2, c-Jun, p38, and NF- $\kappa$ B was observed at the optimal timing of $30 \mathrm{~min}, 15 \mathrm{~min}, 2 \mathrm{~h}$, and $30 \mathrm{~min}$ incubation, respectively. In agreement with these findings, activation of the MAP kinases (ERK1/2, p38), JNK, and NF$\kappa \mathrm{B}$ was reported during oxidative stress, obesity, TLR engagement, metabolic inflammation, or insulin resistance [55-58]. Notably, metabolic stress may involve both ROS and reactive nitrogen species (RNS). Besides inflicting a direct macromolecular damage to DNA, proteins and lipids, ROS/RNS may also indirectly damage tissues/organs by activating the cellular stress pathways including p38 MAPK, JNK, and NF- $\mathrm{kB}$ [59]. Nonetheless, the present study is limited by certain caveats e.g. changes specific to different cell types present in PBMC as well as effect of $\mathrm{H}_{2} \mathrm{O}_{2}$-induced oxidative stress on insulin signaling or glucose transport remain unclear which will be preferentially addressed in our subsequent investigations.

\section{Conclusion}

Taken together, our data show the elevated mRNA/protein expression of TLR2/4 following $\mathrm{H}_{2} \mathrm{O}_{2}$-induced oxidative stress in PBMC. Leptin, LPS, oleate, and palmitate, each, interacts cooperatively with $\mathrm{H}_{2} \mathrm{O}_{2}$ to accentuate oxidative stress and further promote TLR2/4 expression. These changes are paralleled by enhanced expression of IRF3/5 and signature proinflammatory cytokines. $\mathrm{H}_{2} \mathrm{O}_{2}$-induced ROS-driven oxidative stress in PBMC involves the MAPK/NF- $\kappa B$ dependent signaling. We speculate that TLR2/4 upregulation in PBMC may represent an additional hypoxia-sensitive target for ROS-suppressive/anti-oxidant strategies to alleviate metabolic inflammation. 


\section{Cellular Physiology Cell Physiol Biochem 2019;53:1-18

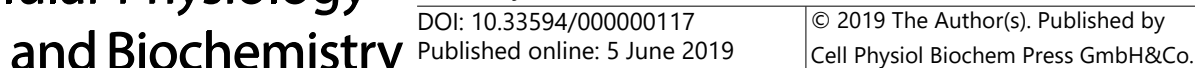 \\ Akhter et al.: Oxidative Stress Induces TLR2/4 Expression in Human PBMC}

\section{Abbreviations}

TLRs (Toll-like receptors); TIR (Toll/IL-1 receptor); MyD-88 (Myeloid differentiation factor-88); IRAK (IL1R-associated kinase); TRAF (Tumor necrosis factor receptor-associated factor); ERK (Extracellular signal-regulated kinase); JNK (c-Jun N-terminal kinase); MAPK (Mitogen-activated protein kinases); NF- $\kappa \mathrm{B}$ (Nuclear factor $\kappa \mathrm{B}$ ); MAPK (Mitogen activated protein kinase); T2D (Type-2 diabetes); PBMC (Peripheral blood mononuclear cells); FBS (Fetal bovine serum); $\mathrm{H}_{2} \mathrm{O}_{2}$ (Hydrogen peroxide); MGB (Minor groove binder); FAM (Fluorescein amidite); NFQ (Non-fluorescent quencher); UDG (Uracil-DNA-glycosylase); BFA (Brefeldin A); PE (Phycoerythrin); FITC (Fluorescein isothiocyanate); APC (Allophycocyanin); DCF (2'-7'dichlorofluorescein); DCFH-DA (2'-7'dichlorofluorescein diacetate); DAPI (4',6-diamidino-2-phenylindole); RIPA buffer (Radioimmunoprecipitation assay buffer); SDS (Sodium dodecyl sulfate); SDS-PAGE (Sodium dodecyl sulfate polyacrylamide gel electrophoresis); PVDF (Polyvinylidene fluoride); TBS (Tris-buffered saline); HRP (Horse radish peroxidase); IRF (Interferon regulatory factor); MFI (Mean fluorescence intensity); SI (Staining index); ROS (Reactive oxygen species); RNS (Reactive nitrogen species); NAC (N-acetyl cysteine); FOXO1 (Forkhead box protein-01); ANOVA (Analysis of variance).

\section{Acknowledgements}

The authors thank the laboratory support staff for donating blood and DDI phlebotomy personnel for help with blood collection. The experimental work was conducted with the human blood donors' understanding and informed consent, and as per the institutional ethics committee guidelines. This work was supported by funds from Kuwait Foundation for the Advancement of Sciences (KFAS) (Grants \#: RA 2015-027; RA AM-2016-007).

NA performed experiments, acquired and analyzed data as well as prepared graphs; AM was involved in technical feedback, manuscript review and editing; HA participated in data interpretation, manuscript drafting and review; AW performed western blotting and acquired data; SK contributed to data acquisition, analysis and graphics preparation; RT performed confocal microscopy, data acquisition and analysis; SS contributed to some experiments and acquired data; FAM provided technical guidance, reviewed and edited the manuscript; RA was involved in study designing, fund acquisition, data analysis and manuscript review; \& SS designed and coordinated experimental work, acquired funds, analyzed/interpreted data, prepared graphics, and wrote the manuscript. All authors read and approved the final manuscript.

\section{Disclosure Statement}

The authors declare that they have no competing interests involved.

\section{References}

1 Akira S, Uematsu S, Takeuchi O: Pathogen recognition and innate immunity. Cell 2006;124:783-801.

2 Trudler D, Farfara D, Frenkel D: Toll-like receptors expression and signaling in glia cells in neuro-amyloidogenic diseases: towards future therapeutic application. Mediators Inflamm 2010;2010:pii:497987.

3 Akira S, Takeda K: Toll-like receptor signalling. Nature Rev Immunol 2004;4:499-511.

4 Baccala R, Hoebe K, Kono DH, Beutler B, Theofilopoulos AN: TLR-dependent and TLR-independent pathways of type I interferon induction in systemic autoimmunity. Nat Med 2007;13:543-551.

5 Sengenes C, Miranville A, Lolmede K, Curat CA, Bouloumie A: The role of endothelial cells in inflamed adipose tissue. J Intern Med 2007;262:415-421. 


\section{Cellular Physiology Cell Physiol Biochem 2019;53:1-18 \begin{tabular}{c|c|c|c|}
\hline DOl: $10.33594 / 000000117$ & 02019 The Author(s). Published by \\
\hline and Biochemistry
\end{tabular} \\ \begin{tabular}{l|l} 
Published online: 5 June 2019 & Cell Physiol Biochem Press GmbH\&Co. KG \\
\hline
\end{tabular} \\ Akhter et al.: Oxidative Stress Induces TLR2/4 Expression in Human PBMC}

6 Iwahashi M, Yamamura M, Aita T, Okamoto A, Ueno A, Ogawa N, Akashi S, Miyake K, Godowski PJ, Makino $\mathrm{H}$ : Expression of Toll-like receptor 2 on CD16+ blood monocytes and synovial tissue macrophages in rheumatoid arthritis. Arthritis Rheum 2004;50:1457-1467.

7 Cario E, Podolsky DK: Differential alteration in intestinal epithelial cell expression of toll-like receptor 3 (TLR3) and TLR4 in inflammatory bowel disease. Infect Immun 2000;68:7010-7017.

8 Sabroe I, Whyte MK, Wilson AG, Dower SK, Hubbard R, Hall I: Toll-like receptor (TLR) 4 polymorphisms and COPD. Thorax 2004;59:81.

9 Dasu MR, Devaraj S, Park S, Jialal I: Increased toll-like receptor (TLR) activation and TLR ligands in recently diagnosed type 2 diabetic subjects. Diabetes Care 2010;33:861-868.

10 Balistreri CR, Caruso C, Candore G: The role of adipose tissue and adipokines in obesity-related inflammatory diseases. Mediators Inflamm 2010;2010:802078.

11 Guzik TJ, Skiba DS, Touyz RM, Harrison DG: The role of infiltrating immune cells in dysfunctional adipose tissue. Cardiovasc Res 2017;113:1009-1023.

12 Mraz M, Haluzik M: The role of adipose tissue immune cells in obesity and low-grade inflammation. J Endocrinol 2014;222:R113-127.

13 Cildir G, Akincilar SC, Tergaonkar V: Chronic adipose tissue inflammation: all immune cells on the stage. Trends Mol Med 2013;19:487-500.

14 Ye J: Adipose tissue vascularization: its role in chronic inflammation. Curr Diab Rep 2011;11:203-210.

15 Furukawa S, Fujita T, Shimabukuro M, Iwaki M, Yamada Y, Nakajima Y, Nakayama O, Makishima M, Matsuda M, Shimomura I: Increased oxidative stress in obesity and its impact on metabolic syndrome. J Clin Invest 2004;114:1752-1761.

16 Ahmad R, Al-Mass A, Atizado V, Al-Hubail A, Al-Ghimlas F, Al-Arouj M, Bennakhi A, Dermime S, Behbehani K: Elevated expression of the toll like receptors 2 and 4 in obese individuals: its significance for obesityinduced inflammation. J Inflamm (Lond) 2012;9:48.

17 Devaraj S, Dasu MR, Rockwood J, Winter W, Griffen SC, Jialal I: Increased toll-like receptor (TLR) 2 and TLR4 expression in monocytes from patients with type 1 diabetes: further evidence of a proinflammatory state. J Clin Endocrinol Metab 2008;93:578-583.

18 Kim JJ, Sears DD: TLR4 and Insulin Resistance. Gastroenterol Res Pract 2010;2010:pii:212563.

19 Reyna SM, Ghosh S, Tantiwong P, Meka CS, Eagan P, Jenkinson CP, Cersosimo E, Defronzo RA, Coletta DK, Sriwijitkamol A, Musi N: Elevated toll-like receptor 4 expression and signaling in muscle from insulinresistant subjects. Diabetes 2008;57:2595-2602.

20 Shi H, Kokoeva MV, Inouye K, Tzameli I, Yin H, Flier JS: TLR4 links innate immunity and fatty acid-induced insulin resistance. J Clin Invest 2006;116:3015-3025.

21 Zhao GN, Jiang DS, Li H: Interferon regulatory factors: at the crossroads of immunity, metabolism, and disease. Biochim Biophys Acta 2015;1852:365-378.

22 Sindhu ST, Ahmad R, Morisset R, Ahmad A, Menezes J: Peripheral blood cytotoxic gammadelta T lymphocytes from patients with human immunodeficiency virus type 1 infection and AIDS lyse uninfected CD4+ T cells, and their cytocidal potential correlates with viral load. J Virol 2003;77:1848-1855.

23 Poulain-Godefroy O, Le Bacquer O, Plancq P, Lecoeur C, Pattou F, Fruhbeck G, Froguel P: Inflammatory role of Toll-like receptors in human and murine adipose tissue. Mediators Inflamm 2010;2010:823486.

24 Creely SJ, McTernan PG, Kusminski CM, Fisher f M, Da Silva NF, Khanolkar M, Evans M, Harte AL, Kumar S: Lipopolysaccharide activates an innate immune system response in human adipose tissue in obesity and type 2 diabetes. Am J Physiol Endocrinol Metab 2007;292:E740-747.

25 Devaraj S, Jialal I, Yun JM, Bremer A: Demonstration of increased toll-like receptor 2 and toll-like receptor 4 expression in monocytes of type 1 diabetes mellitus patients with microvascular complications. Metabolism 2011;60:256-259.

26 Liu ZW, Wang JK, Qiu C, Guan GC, Liu XH, Li SJ, Deng ZR: Matrine pretreatment improves cardiac function in rats with diabetic cardiomyopathy via suppressing ROS/TLR-4 signaling pathway. Acta Pharmacol Sin 2015;36:323-333.

27 Dasu MR, Devaraj S, Zhao L, Hwang DH, Jialal I: High glucose induces toll-like receptor expression in human monocytes: mechanism of activation. Diabetes 2008;57:3090-3098.

28 Kaur H, Chien A, Jialal I: Hyperglycemia induces Toll like receptor 4 expression and activity in mouse mesangial cells: relevance to diabetic nephropathy. Am J Physiol Renal Physiol 2012;303:F1145-1150. 


\section{Cellular Physiology Cell Physiol Biochem 2019;53:1-18 \begin{tabular}{c|c|c|c|}
\hline DOl: $10.33594 / 000000117$ & 019 \\
and The Author(s). Published by
\end{tabular} \\ \begin{tabular}{l|l} 
Published online: 5 June 2019 & Cell Physiol Biochem Press GmbH\&Co. KG \\
\hline
\end{tabular} \\ Akhter et al.: Oxidative Stress Induces TLR2/4 Expression in Human PBMC}

29 Li C, Jackson RM: Reactive species mechanisms of cellular hypoxia-reoxygenation injury. Am J Physiol Cell Physiol 2002;282:C227-241.

30 Kim D, Kim YJ, Koh HS, Jang TY, Park HE, Kim JY: Reactive oxygen species enhance TLR10 expression in the human monocytic cell line THP-1. Int J Mol Sci 2010;11:3769-3782.

31 Jin X, Wang L, Wu HS, Zhang L, Wang CY, Tian Y, Zhang JH: N-acetylcysteine inhibits activation of toll-like receptor 2 and 4 gene expression in the liver and lung after partial hepatic ischemia-reperfusion injury in mice. Hepatobiliary Pancreat Dis Int 2007;6:284-289.

32 Rajamani U, Jialal I: Hyperglycemia induces Toll-like receptor-2 and -4 expression and activity in human microvascular retinal endothelial cells: implications for diabetic retinopathy. J Diabetes Res 2014;2014:790902.

33 Arner P, Ryden M: Fatty Acids, Obesity and Insulin Resistance. Obes Facts 2015;8:147-155.

34 Reaven GM, Hollenbeck C, Jeng CY, Wu MS, Chen YD: Measurement of plasma glucose, free fatty acid, lactate, and insulin for $24 \mathrm{~h}$ in patients with NIDDM. Diabetes 1988;37:1020-1024.

35 Neves AL, Coelho J, Couto L, Leite-Moreira A, Roncon-Albuquerque R Jr:: Metabolic endotoxemia: a molecular link between obesity and cardiovascular risk. J Mol Endocrinol 2013;51:R51-R64.

36 Flier JS: Clinical review 94: What's in a name? In search of leptin's physiologic role. J Clin Endocrinol Metab 1998;83:1407-1413.

37 Xiang M, Fan J, Fan J: Association of Toll-like receptor signaling and reactive oxygen species: a potential therapeutic target for posttrauma acute lung injury. Mediators Inflamm 2010;2010:pii:916425.

38 Ahmad R, Akhter N, Al-Roub A, Kochumon S, Wilson A, Thomas R, Ali S, Tuomilehto J, Sindhu S: MIP-1alpha Induction by Palmitate in the Human Monocytic Cells Implicates TLR4 Signaling Mechanism. Cell Physiol Biochem 2019;52:212-224.

39 Kochumon S, Wilson A, Chandy B, Shenouda S, Tuomilehto J, Sindhu S, Ahmad R: Palmitate Activates CCL4 Expression in Human Monocytic Cells via TLR4/MyD88 Dependent Activation of NF-kappaB/MAPK/ PI3K Signaling Systems. Cell Physiol Biochem 2018;46:953-964.

40 Sindhu S, Akhter N, Kochumon S, Thomas R, Wilson A, Shenouda S, Tuomilehto J, Ahmad R: Increased Expression of the Innate Immune Receptor TLR10 in Obesity and Type-2 Diabetes: Association with ROSMediated Oxidative Stress. Cell Physiol Biochem 2018;45:572-590.

41 Eguchi J, Yan QW, Schones DE, Kamal M, Hsu CH, Zhang MQ, Crawford GE, Rosen ED: Interferon regulatory factors are transcriptional regulators of adipogenesis. Cell Metab 2008;7:86-94.

42 Platanitis E, Decker T: Regulatory Networks Involving STATs, IRFs, and NFkappaB in Inflammation. Front Immunol 2018;9:2542.

43 Thompson CD, Matta B, Barnes BJ: Therapeutic Targeting of IRFs: Pathway-Dependence or StructureBased? Front Immunol 2018;9:2622.

44 Kumari M, Wang X, Lantier L, Lyubetskaya A, Eguchi J, Kang S, Tenen D, Roh HC, Kong X, Kazak L, Ahmad R, Rosen ED: IRF3 promotes adipose inflammation and insulin resistance and represses browning. J Clin Invest 2016;126:2839-2854.

45 Zhang Y, Li H: Reprogramming Interferon Regulatory Factor Signaling in Cardiometabolic Diseases. Physiology (Bethesda) 2017;32:210-223.

46 Takaoka A, Yanai H, Kondo S, Duncan G, Negishi H, Mizutani T, Kano S, Honda K, Ohba Y, Mak TW, Taniguchi T: Integral role of IRF- 5 in the gene induction programme activated by Toll-like receptors. Nature 2005;434:243-249.

47 Schoenemeyer A, Barnes BJ, Mancl ME, Latz E, Goutagny N, Pitha PM, Fitzgerald KA, Golenbock DT: The interferon regulatory factor, IRF5, is a central mediator of toll-like receptor 7 signaling. J Bio Chem 2005;280:17005-17012.

48 Hensley K, Robinson KA, Gabbita SP, Salsman S, Floyd RA: Reactive oxygen species, cell signaling, and cell injury. Free Radic Biol Med 2000;28:1456-1462.

49 Marseglia L, Manti S, D’Angelo G, Nicotera A, Parisi E, Di Rosa G, Gitto E, Arrigo T: Oxidative stress in obesity: a critical component in human diseases. Int J Mol Sci 2014;16:378-400.

50 Popko K, Gorska E, Stelmaszczyk-Emmel A, Plywaczewski R, Stoklosa A, Gorecka D, Pyrzak B, Demkow U: Proinflammatory cytokines Il-6 and TNF-alpha and the development of inflammation in obese subjects. Eur J Med Res 2010;15:120-122. 


\section{Cellular Physiology Cell Physiol Biochem 2019;53:1-18 \begin{tabular}{ll|l} 
and Biochemistry & $\begin{array}{l}\text { DOl: } 10.33594 / 000000117 \\
\text { Published online: } 5 \text { June } 2019\end{array}$ & $\begin{array}{l}\text { O } 2019 \text { The Author(s). Published by } \\
\text { Cell Physiol Biochem Press GmbH\&Co. KG }\end{array}$ \\
\cline { 2 - 3 }
\end{tabular} \\ Akhter et al.: Oxidative Stress Induces TLR2/4 Expression in Human PBMC}

51 Kang YE, Kim JM, Joung KH, Lee JH, You BR, Choi MJ, Ryu MJ, Ko YB, Lee MA, Lee J, Ku BJ, Shong M, Lee KH, Kim HJ: The Roles of Adipokines, Proinflammatory Cytokines, and Adipose Tissue Macrophages in Obesity-Associated Insulin Resistance in Modest Obesity and Early Metabolic Dysfunction. PloS One 2016;11:e0154003.

52 Sonoda J, Laganiere J, Mehl IR, Barish GD, Chong LW, Li X, Scheffler IE, Mock DC, Bataille AR, Robert F, Lee $\mathrm{CH}$, Giguere V, Evans RM: Nuclear receptor ERR alpha and coactivator PGC-1 beta are effectors of IFNgamma-induced host defense. Genes Dev 2007;21:1909-1920.

53 Yang D, Elner SG, Bian ZM, Till GO, Petty HR, Elner VM: Pro-inflammatory cytokines increase reactive oxygen species through mitochondria and NADPH oxidase in cultured RPE cells. Exp Eye Res 2007;85:462472.

54 Woo CH, Eom YW, Yoo MH, You HJ, Han HJ, Song WK, Yoo YJ, Chun JS, Kim JH: Tumor necrosis factoralpha generates reactive oxygen species via a cytosolic phospholipase A2-linked cascade. J Bio Chem 2000;275:32357-32362.

55 Tanti JF, Ceppo F, Jager J, Berthou F: Implication of inflammatory signaling pathways in obesity-induced insulin resistance. Front Endocrinol 2012;3:181.

56 McArdle MA, Finucane OM, Connaughton RM, McMorrow AM, Roche HM: Mechanisms of obesity-induced inflammation and insulin resistance: insights into the emerging role of nutritional strategies. Front Endocrinol 2013;4:52.

57 Carlsen H, Haugen F, Zadelaar S, Kleemann R, Kooistra T, Drevon CA, Blomhoff R: Diet-induced obesity increases NF-kappaB signaling in reporter mice. Genes Nutr 2009;4:215-222.

58 Baker RG, Hayden MS, Ghosh S: NF-kappaB, inflammation, and metabolic disease. Cell Metab 2011;13:1122.

59 Evans JL, Goldfine ID, Maddux BA, Grodsky GM: Are oxidative stress-activated signaling pathways mediators of insulin resistance and beta-cell dysfunction? Diabetes 2003;52:1-8. 